Wahana Didaktika Vol. 18 No.3 September 2020 : 316-328

\title{
IMPLEMENTASI SIKAP DEMOKRATIS DALAM PEMBELAJARAN PKn PADA SISWA SD
}

\author{
Oleh: Mitra Ayu, M. Idris, Adrianus Dedy \\ Email : adrianusdedy@univpgri-palembang.ac.id \\ (Universitas PGRI Palembang)
}

\begin{abstract}
Abstrak
Tujuan dari penelitian ini untuk mendeskripsikan dan mengetahui apakah Sikap-Sikap Demokratis sudah diterapkan dalam proses pembelajaran PKn kelas II SD Negeri 204 Palembang. Penelitian ini merupakan jenis penelitian kualitatif. Dalam penelitian ini yang menjadi Subjek penelitian adalah siswa kelas II SD Negeri 204 Palembang yang berjumlah 33 orang. Metode yang dipergunakan dalam penelitian ini adalah metode kualitatif. Hasil penelitian menunjukkan bahwa Implementasi Sikap Demokratis dalam Proses Pembelajaran adalah guru mengintegrasikan sikap demokratis dalam pembelajaran PKn. Pengimplementasi-an sikap demokratis dalam proses pembelajaran dilaksanakan menjadi tahap perencanaan dan tahap pelaksanaan. Menggunakan perangkat pembelajaran seperti silabus dan RPP. Sedangkan pada tahap pelaksanaan, guru melaksanakan proses pembelajaran di kelas dengan penggunaan metode Tanya jawab untuk mendorong siswa agar bisa menerapkan sikap demokratis dalam proses tanya jawab di kelas. Implementasi sikap-sikap demokrasi yang dapat di implementasikan dalam proses pembelajaran PKn di sekolah Dasar Negeri 204 Palembang diantaranya (1) Kebebasan berpendapat, (2) Toleransi, (3) Kepercayaan diri, (4) Kesadaran akan perbedaan, (5) Menghormati orang lain.
\end{abstract}

Kata Kunci : Sikap-Sikap Demokratis, Pembelajaran PKn

\section{IMPLEMENTATION OF DEMOCRATIC ATTITUDES IN Civics LEARNING IN SD STUDENTS}

\begin{abstract}
The purpose of this study is to describe and find out whether Democratic Attitudes have been applied in the learning process of Class II Civics in 204 Palembang Elementary School. This research is a type of qualitative research. In this study, the subject of the study was 33 second grade Palembang Elementary School students in Palembang. The method used in this study is a qualitative method. The results showed that the Implementation of Democratic Attitudes in the Learning Process is that teachers integrate democratic attitudes in learning Civics. Implementing a democratic attitude in the learning process is carried out into the planning and implementation stages. Use learning tools such as syllabus and lesson plans. While at the implementation stage, the teacher carries out the learning process in the classroom by using the Question and Answer method to encourage students to be able to apply a democratic attitude in the Question and Answer process in the classroom. Implementation of democratic attitudes that can be implemented in the Civics learning process in Palembang 204 Primary Schools
\end{abstract}


Implementasi Sikap Demokratis.... (Mitra Ayu, M. Idris, Adrianus Dedy)

including (1) Freedom of opinion, (2) Tolerance, (3) Self-confidence, (4) Awareness of differences, (5) Respect for others.

Keywords: Democratic Attitudes, Civic Education Learning

\section{A. PENDAHULUAN}

Indonesia merupakan salah satu negara yang menganut sistem pemerintahan demokrasi. Sejak dahulu bangsa Indonesia telah mempraktekkan ide tentang demokrasi meskipun masih pada tingkat yang sederhana dan belum mencakup demokrasi dalam tingkat kenegaraan. Demokrasi pada masa itu sering disebut dengan demokrasi asli yang diwujudkan dengan kegiatan rapat rembug desa, gotong-royong, pemilihan kepala desa dan lain-lain. Pada masa modern ini, Indonesia telah mengembangkan sistem demokrasi yang telah disesuaikan dengan konteks perkembangan zaman (Paramita, 2016:285).

Guna mewujudkan negara dengan budaya yang demokratis, dibutuhkan penanaman sikap demokratis sejak dini, dimulai dari pendidikan, salah satunya pada tingkat sekolah dasar. Sekolah dasar berperan sangat besar dalam menanamkan sikap demokratis pada peserta didik melalui beberapa kegiatan pembelajaran yang diintegrasikan dalam beberapa mata pelajaran dan berbagai kegiatan sekolah di luar jam pelajaran, seperti: ekstrakulikuler maupun beberapa tata tertib guna membudayakan sikap demokratis di lingkungan sekolah.

Untuk itu, perlunya pendidikan kewarganegaraan diajarkan di sekolah dasar ialah agar siswa sejak dini dapat memahami dan mampu melaksanakan hakhak dan kewajibannya untuk menjadi warga negara yang cerdas, terampil, dan berkarakter yang diamanatkan oleh pancasila dan UUD 1945, dan memahami nilai-nilai kedisiplinan, kejujuran dan sikap yang baik terhadap sesamanya, lawan jenisnya, maupun terhadap orang yang lebih tua. Melalui materi pendidikan kewarganegaraan, juga dapat mendidik siswa agar dapat berfikir kritis, rasional, dan kreatif dalam menanggapi isu kewarganegaraan, serta berpartisipasi secara aktif dan bertanggung jawab dan bertindak secara cerdas, terampil dan berkarakter (Paramita, 2016:286). 
Pentingnya pendidikan kewarganegaraan diajarkan disekolah dasar ialah memberikan pelajaran pada siswa untuk memahami dan membiasakan dirinya dalam kehidupan di sekolah atau diluar sekolah, karena materi kewarganegaraan menekankan pada pengamalan dan pembiasaan dalam kehidupan sehari-hari yang ditunjang oleh pengetahuan dan pengertian sederhana sebagai bekal untuk mengikuti pendidikan berikutnya (Paramita, 2016:287).

Namun, sangat disayangkan bahwa dalam aplikasinya, mata pelajaran PKn seperti materi tentang musyawarah yang mengajarkan sikap demokratis pada siswa belum maksimal dan kurang banyak diminati dan dikaji dalam dunia pendidikan dan persekolahan, karena kebanyakan lembaga pendidikan formal dominan pada penyajian materi yang bersifat kognitif dan psikomotorik belaka, kurang menyentuh pada aspek afektif. Berdasarkan hasil observasi dan wawancara peneliti dengan salah satu guru kelas II yang bernama Nur Purnama Sari di SD Negeri 204 Palembang, dia mengatakan bahwa permasalahanpermasalahan yang sering terjadi yaitu pada kegiatan pembelajaran yang dilakukan siswa SD di dalam kelas seperti (1) siswa sangat individual (2) sulit untuk bekerja sama dan (3) tidak dapat menghargai keputusan orang lain.

Berdasarkan latar belakang tersebut, peneliti akan mendeskripsikan sikap demokratis dalam pembelajaran PKn dengan melakukan penelitian dengan judul "Implementasi Sikap Demokrasi dalam Proses Pembelajaran PKn kelas II di SD Negeri 204 Palembang".Berdasarkan uraian rumusan masalah diatas maka tujuan penelitian ini adalah untuk mengetahui implementasi sikap demokratis dalam pembelajaran PKn pada Siswa Kelas II di SDN 204 Palembang.

\section{B. METODOLOGI PENELITIAN}

Metode yang digunakan adalah metode deskriptif kualitatif. Tylor dalam Amirudin (2019:39) mengemukakan bahwa metodologi kualitatif merupakan prosedur penelitian yang menghasilkan data deskriptif berupa kata-kata tertulis maupun lisan dari orang-orang perilaku yang diamati. 
Implementasi Sikap Demokratis.... (Mitra Ayu, M. Idris, Adrianus Dedy)

\section{Reduksi Data}

Reduksi data yaitu kegiatan memilih data, merangkum hal-hal pokok yang sesuai dengan topik penelitian ini yaitu mengenai implementasi Sikap demokratis Serta menyusun data yang terpilah di SD Negeri 204 Palembang. secara sistematis sehingga memberikan gambaran yang jelas tentang hasil penelitian. Dalam penelitian ini, reduksi data dilakukan untuk memfokuskan hasil wawancara, observasi, dan dokumentasi pada kepala sekolah, guru dan siswa di SD Negeri 204 Palembang.

\section{Penyajian Data}

Setelah tahap reduksi data, proses selanjutnya adalah melakukan penyajian data. Penyajian data bertujuan untuk mempermudah peneliti dalam menguasai dan memahami data yang telah dikumpulkan. Data yang dikumpulkan dalam penelitian ini terkait dengan implementasi sikap demokratis yang ada di SD Negeri 204 Palembang.Penyajian data dapat dilakukan dalam bentuk uraian singkat, tabel, grafik, diagram, matriks ataupun bentuk yang lebih sederhana dan mudah dipahami. Penyajian data yang akan digunakan dalam penelitian ini akan disesuaikan dengan hasil analisis data di lapangan nantinya.

3. Penarikan Kesimpulan

Penarikan kesimpulan dilakukan dengan melihat hasil reduksi data dan tetap mengacu pada rumusan masalah serta tujuan yang hendak dicapai. Penarikan kesimpulan dalam penelitian ini dilakukan dengan cara membandingkan data yang diperoleh dari hasil wawancara, observasi dan dokumentasi untuk mengetahui implementasi Sikap Demokratis di SD Negeri 204 Palembang.

\section{HASIL PENELITIAN DAN PEMBAHASAN}

Berdasarkan hasil wawancara menjelaskan bahwa aktivitas pembelajaran yang dilakukan oleh guru ini kelihatannya memang biasa saja dan sering dilakukan oleh sebagian besar guru lainnya, namun memberikan makna yang luas. Menghormati orang lain melalui sikap berdemokratis merupakan salah satu sikap yang harus disiapkan sebelum sikap demokrasi dijalankan. Jika hal ini tidak 
menjadi sikap bersama maka demokrasi akan berjalan dengan kebebasan yang tidak bertanggung jawab dan akan ada yang merasa dirugikan.

Berdasarkan hasil observasi yang peneliti lakukan pada tanggal 20 April 2020, dapat dilihat pada saat proses pembelajaran PKn kelas IIB yang sedang berlangsung, siswa melakukan aktifitas tanya jawab di kelas. Setiap siswa dibebaskan untuk bertanya maupun menjawab di dalam proses pembelajaran yang sedang berlangsung. Siswa bebas mengeluarkan pendapat mereka tentang pertanyaan yang diberikan oleh guru dan siswa diminta untuk menyelesaikan tugas latihan yang diberikan oleh guru di kelas. Guru juga meminta agar siswa untuk bersikap demokratis pada saat tanya jawab berlangsung seperti saling menghargai pendapat sesama teman, saling bertoleransi, tidak boleh egois, siswa juga dilatih untuk bisa percaya diri dengan adanya dorongan dan dukungan motivasi dari guru di kelas sehingga proses tanya jawab berjalan dengan baik.

Guru berusaha untuk menjadi seorang suri teladan yang baik bagi peserta didik dalam proses pelaksanaan pembelajaran di kelas. Dalam proses pelaksanaan pembelajaran di kelas juga terdapat beberapa faktor pendukung yang memang tidak bisa terlepas dari terlaksananya proses pembelajaran diantaranya; Pertama, fasilitas sarana dan prasarana yang disediakan di sekolah memang sudah cukup memadai untuk dipergunakan siswa maupun guru. Kedua, siswa diberikan motivasi oleh guru, dengan adanya dorongan motivasi yang di berikan oleh guru, siswa akan menjadi lebih bersemangat dan suasana kelas menjadi lebih kondusif.

Pemberian motivasi pada siswa ini juga diharapkan agar siswa mampu mengkuti proses pembelajaran dengan lebih baik sehingga siswa dapat maksimal dalam proses pembelajaran agar tercapai hasil yang sesuai dengan harapan bersama. Selain itu, guru dalam mengajar juga santai, hal ini menunjukkan bahwa tidak terdapat unsur-unsur paksaan atau otoriter dalam proses pembelajaran di kelas sehingga dapat dikatakan bahwa guru telah mampu mengimplementasikan sikap-sikap demokratis di dalam proses pembelajaran dengan baik. 


\section{PEMBAHASAN}

Bagian pembahasan dalam penelitian ini akan mendeskripsikan hasil penelitian yang telah peneliti lakukan dan jelaskan sebelumnya. Pembahasan dalam penelitian ini mengacu pada hasil penelitian yang telah peneliti lakukan berdasarkan hasil wawancara dan hasil observasi yang telah peneliti lakukan pada tanggal 20 April 2020 di Sekolah Dasar Negeri 204 Palembang.

\section{Pentingnya sikap demokrasi}

Hasil penelitian menunjukkan bahwa dalam proses pembelajaran guru di SD Negeri 204 Palembang telah memahami nilai-nilai demokrasi yang kemudian akan diajarkan kepada siswa melalui kegiatan pembelajaran. Sikap demokratis menurut pemahaman kepala sekolah adalah perilaku yang dimiliki siswa maupun guru dimana mereka memiliki kebebasan berpendapat, saling menghargai, dan tidak egois satu dengan yang lainnya.Sikap demokratis juga menjunjung tinggi rasa tanggung jawab, contohnya guru bisa mengajarkan siswa untuk berlaku adil seperti tidak membedakan siswa yang satu dengan siswa lainnya.

Sikap demokratis menurut pemahaman guru adalah sikap yang harus diterapkan oleh guru. Sikap demokratis membutuhkan prinsip kebebasan berpendapat terutama untuk siswa, kesamaan hak dan kewajiban tiap siswa, dan guru harus berusaha menciptakan rasa persaudaraan antara guru dan siswa dalam proses pembelajaran.

Pemahaman kepala sekolah dan guru di atas sesuaidengan pendapat Sardiman dalam Susanto (2016:11) yang mengungkapkan bahwa sikap merupakan kecenderungan untuk melakukan sesuatu dengan cara, metode, pola, dan teknik tertentu terhadap dunia sekitarnya baik berupa individu-individu maupun objek-objek tertentu. Artinya, sikap merupakan kecenderungan untuk melakukan sesuatu terhadap lingkungan yang berada di sekitarnya.

Hasil penelitian juga menunjukan bahwa sikap demokratis penting diterapkan di sekolah terutamabagi siswa karena dengan sikap-sikap demokratis siswa akanmembentuk jati diri untuk mengendalikan sifat egois, individual, sertadapat mewujudkan suasana yang damai, saling menghargai antarsiswa. Hal tersebut sesuai dengan pendapat Beane dan Apple dalam Rosyada (2004:16), 
menjelaskan berbagai kondisi yang sangat perlu dikembangkan dalam upaya membangun sekolah demokratis adalah sebagai berikut: (1) Keterbukaan saluran ide dan gagasan, sehingga semua orang bisa menerima informasi seoptimal mungkin; (2) Memberikan kepercayaan kepada individu-individu dan kelompok dengan kapasitas yang mereka miliki untuk menyelesaikan berbagai persoalan sekolah; (3) Menyampaikan kritik sebagai hasil analisis dalam proses penyampaian evaluasi terhadap ide-ide, problem-problem dan berbagai kebijakan yang dikeluarkan sekolah; (4) Memperlihatkan kepedulian terhadap kesejahteraan orang lain dan terhadap persoalan-persoalan publik; (5) Ada kepedulian terhadap harga diri, hak-hak individu, dan hak-hak minoritas; (6) Pemahaman bahwa demokrasi yang dikembangangkan belumlah mencerminkan demokrasi yang diidealkan, sehingga demokrasi harus terus dikembangkan dan bisa membimbing keseluruhan hidup manusia; (7) Terdapat sebuah institusi yang dapat terus mempromosikan dan mengembangkan cara-cara hidup demokratis.

Berdasarkan pendapat di atas dapat disimpulkan bahwa pentingnya sikap demokratis dalam kehidupan sehari-hari terutama dalam lingkungan di sekolah. Hal ini akan membentuk sikap saling menghargai dengan orang lain, damai, tidak egois, tidak individual dengan kata lain tidak mendahulukan kepentingan diri sendiri melainkan harus mementingkan kepentingan orang banyak juga, serta dengan mudah mengatasi permasalahan dan mengambil keputusan dengan jalan musyawarah.

\section{Pengimplementasian Sikap Demokratis dalam Proses Pembelajaran PKn}

Adapun hasil pembahasan dari penelitian yang telah peneliti lakukan untuk berusaha menjawab penelitian ini yaitu tentang implementasi sikap demokrasi dalam proses pembelajaran di Sekolah Dasar Negeri 204 Palembang, yang dilaksanakan melalui tahap perencanaan dan tahap pelaksanaan, pembahasan yang dapat diuraikan sebagai berikut:

a. Perencanaan

Sebelum proses pembelajaran PKn kelas II di Sekolah Dasar Negeri 204 Palembang berlangsung, guru telah memuat perencanaan pembelajaran ke dalam 
perangkat pembelajaran terlebih dahulu seperti silabus dan Rencana Pelaksanaan Pembelajaran (RPP), dalam perangkat pembelajaran tersebut guru telah mengimplementasikan sikap-sikap demokratis, sikap demokratis yang tertulis dalam silabus dan Rencana Pelaksanaan Pembelajaran (RPP) tersebut diantaranya menghormati (respect) dan tanggung jawab (responsibility).

Perencanaan yang dilakukan sebelum proses pembelajaran berlangsung sangat penting, karena dalam Rencana Pelaksanaan Pembelajaran (RPP) kelas II yang dibuat oleh guru telah memuat sikap-sikap demokratis di dalam proses pembelajaran yang akan berlangsung nantinya, materi pembelajaran juga harus bisa membuat siswa aktif di kelas, guru harus bisa menumbuhkan rasa untuk saling menghormati, rasa toleransi, siswa juga harus saling menghargai antar teman maupun guru di kelas.

Hal tersebut sesuai dengan pendapat Novan Ardy (2013:90) yang menyatakan bahwa nilai-nilai dapat di integrasikan dalam proses pembelajaran berupa perencanaan, pelaksanaan, dan evaluasi. Perencanaan pembelajaran pada silabus dan RPP yang telah dibuat guru sudah memuat nilai demokrasi seperti menghormati, tanggung jawab dan demokratis.Silabus dan RPP yang memuat nilainilai karakter diperkuat dengan teori dari Character Counts Coalition (a project of The Joseph Institute of Ethics).

Pendapat di atas juga sependapat dengan kajian terdahulu yang relevan dalam penelitian yang dilakukan oleh Paramita (2016:285) dengan judul "Implementasi Nilai Demokrasi di SD Muhammadiyah Gantiwarno Klaten". Hasil Penelitian ini menunjukkan bahwa implementasi nilai demokrasi di dalam kegiatan pembelajaran adalah guru mengintegrasikan nilai demokrasi dalam mata pelajaran, materi pembelajaran yang mengaktifkan siswa, menumbuhkan rasa toleransi, menghargai antar teman.

\section{b. Pelaksanaan}

Pada pelaksanan pembelajaran, materi pelajaran PKn dikaitkan dengan sikap-sikap di kehidupan sehari-hari.Kegiatan pembelajaran dibuat menyenangkan untuk meningkatkan partisipasi aktif siswa.Hasil penelitian diatas sesuai pendapat Zamroni (2013:23) bahwa pembelajaran yang demokrasi harus menyampaikan 
pesan dan isi yang bermakna.Materi dalam pembelajaran harus berbobot teoritis dan dipadukan dengan realitas masyarakat sekitar sehingga dapat mendorong critical thinking dan kemauan mempraktekan nilai-nilai yang telah diajarkan dalam kehidupan sehari-hari. Pelaksanaan pembelajaran di kelas dikemas dengan kegiatan tanya jawab melalui media benda di sekitar kelas atau sekolah.

Pembelajaran dengan menggunakan metode tanya jawab yang dilakukan kelas IIB di Sekolah Dasar Negeri 204 Palembang juga sesuai dengan pendapat Narwanti dalam Paramita (2016:22) mengungkapkan bahwa dalam mengimplementasikan nilai-nilai karakter yang memuat sikap demokratis dapat dilakukan melalui berbagai kegiatan salah satunya adalah kegiatan pembelajaran. Penerapan nilai-nilai karakter pada pembelajaran dilaksanakan dengan menggunakan strategi yang tepat, yaitu pembelajaran yang mengajak peserta didik menghubungkan materi yang dipelajari dengan kejadian nyata. Artinya bahwa dalam mengimplementasikan nilai-nilai karakter yang memuat sikap demokratis dapat dilakukan melalui kegiatan pembelajaran.

Hal tersebut sesuai dengan Sri Narwanti (2011: 67) yang menggungkapkan bahwa ciri pembelajaran yang menerapkan nilai demokrasi adalah (1) Suasana Pembelajaran dikelas yang dialogis dan Interaktif antara guru dan siswa maupun antar siswa, (2) Keterlibatan semua peserta didik secara aktif selama kegiatan pembelajaran, (3) Menghargai setiap pendapat peserta didik. Pembuatan peraturan di kelas dengan jalan musyawarah menggambarkan kegiatan interaktif antar guru dan siswa yang dapat melibatkan peran aktif siswa ketika proses pembelajaran dan pembuatan peraturan bersama dapat mewujudkan sikap menghargai pendapat orang lain.

Berdasarkan hasil penelitian di lapangan, dapat dijelaskan bahwa sikapsikap demokrasi yang dapat di implementasikan dalam proses pembelajaran PKn di Sekolah Dasar Negeri 204 Palembang diantaranya adalah (1) Kebebasan berpendapat, yaitu setiap peserta didik memiliki hak untuk berpendapat dan bertanya. Dengan menyampaikan penndapatnya setiap peserta didik memiliki tanggung jawab atas segala pertanyaan dan jawaban yang diberikan. (2) Toleransi, setiap peserta didik belajar untuk bertoleransi dengan perbedaan yang ada di 
antara teman temannya. Toleransi dalam perbedaan, tidak membeda bedakan yang berkulit putih dengan hitam, yang pintar dan yang bodoh. Begitupun guru, guru bersikap adil dan memberikan contoh yang baik dalam memperlakukan peserta didiknya. (3) Kepercayaan diri, sikap percaya diri salah satunya dibentuk melalui metode yang diberikan oleh guru di dalam kelas. Guru tidak menyalahkan setiap jawaban yang diberikan oleh peserta didik, dengan begitu kepercayaan diri seorang peserta didik akan terbentuk dengan sendirinya. (4) Kesadaran akan perbedaan, yaitu kesadaran untuk menerima perbedaan yang ada di dalam kelas sejalan dengan prinsip dan sikap-sikap demokratis. Sikap kesetaraan ini hendaknya tetap dijaga dan dijunjung tinggi dalam kehidupan sehari-hari oleh para siswa maupun guru. (5) Menghormati orang lain, menghormati orang lain dalam berdemokratis merupakan salah satu nilai yang harus disiapkan sebelum demokrasi di jalankan. Jika hal ini tidak menjadi sikap bersama maka demokrasi akan berjalan dengan kebebasan yang tidak bertanggung jawab.

Hal ini sesuai dengan pendapat Hendra (2008:67-68), metode dalam demokrasi ditandai dengan adanya kebebasan hak pilih warga negaranya untuk berpartisipasi dalam pengambilan keputusan. Wujud demokrasi yang memungkinkan dilakukan di sekolah ini adalah melalui proses pengambilan keputusan yang melibatkan peran seluruh warga sekolah, dengan jalan musyawarah. Hal ini juga sesuai dengan pendapat Zamroni (2013:19) bahwa nilainilai demokrasi yang dapat diwujudkan dalam kehidupan sehari-hari seperti toleransi, menghargai pendapat, anti kekerasan, berusaha mencari solusi secara damai, mendahulukan kepentingan orang banyak. Sikap toleransi, menghargai pendapat, mencari solusi dengan damai diwujudkan dalam pengambilan keputusan dengan jalan musyawarah ataupun voting.

Pendapat diatas juga sependapat dengan kajian terdahulu yang relevan dalam penelitian yang dilakukan oleh Hemafitria dkk, (2015:173) dengan judul "Implementasi Sikap Demokrasi dalam Proses Pembelajaran Pendidikan Kewarganegaraan”. Hasil Penelitian ini menunjukkan sikap demokrasi adalah prilaku individu, tindakan, perasaan, pandangan yang menjunjung tinggi persamaan, menghargai pendapat orang lain, musyawarah, kebebasan, dan 
tanggung jawab. Seseorang dengan kesiapan atau kecenderungan untuk bertingkah laku mengutamakan kepentingan bersama, menghargai pendapat orang lain secara wajar, jujur, dan terbuka tidak suka memotong pembicaraan orang lain, tidak bersikap egois, akomodatif terhadap kepentingan umum, lebih mengutamakan kemampuan nalar dalam berpendapat, santun, dan tertib dalam memberikan pendapat dan gagasan.

Berdasarkan dari hasil uraian pendapat di atas dapat disimpulkan bahwa pentingnya sikap demokratis dalam proses pembelajaran akan membentuk sikap siswa untuk saling menghargai terhadap orang lain, damai, tidak egois, tidak individual dengan kata lain mendahulukan kepentingan orang banyak, serta dengan mudah mengatasi permasalahan dan mengambil keputusan dengan jalan musyawarah. Sikap demokratis perlu dikembangkan di sekolah terutama di kelas untuk mewariskan perilaku positif pada siswa maupun guru, guna menghadapi tantangan zaman saat ini. Budaya yang senantiasa keluar masuk pada era globalisasi, mengharuskan sekolah sebagai lembaga pendidikan untuk menguatkan karakter peserta didik dengan menerapkan sikap-sikap demokratis. Sekolah menjadi lembaga pendidikan yang melahirkan manusia manusia yang profesional dan kuat guna menghadapi tantangan zaman.

\section{SIMPULAN}

Berdasarkan hasil penelitian dan pembahasan sebelumnya dalam mengidentifikasi implementasi sikap demokratis PKn Kelas II di Sekolah Dasar Negeri 204 Palembang, dilaksanakan melalui tahap perencanaan dan tahap pelaksanaan, yang dapat disimpulkan sebagai berikut:

\section{Perencanaan}

Pada tahap perencanaan pengimplementasian sikap demokratis dalam pembelajaran PKn Kelas II di Sekolah Dasar Negeri 204, guru kelas IIB telah memuat sikap-sikap demokratis di dalam perangkat pembelajaran diantaranya silabus dan Rencana Pelaksanaan Pembelajaran (RPP). Adapun pengimplementasiannya pada silabus dan Rencana Pelaksanaan Pembelajaran (RPP) sudah dimuat nilai-nilai karakteristik seperti sikap demokratis, sikap 
Implementasi Sikap Demokratis.... (Mitra Ayu, M. Idris, Adrianus Dedy)

demokratis yang tertulis dalam silabus dan Rencana Pelaksanaan Pembelajaran (RPP) tersebut diantaranya menghormati (respect) dan tanggung jawab (responsibility).

\section{Pelaksanaan}

Pada tahap pelaksanan proses pembelajaran di kelas IIB, guru menerapkan metode tanya jawab. Pembelajaran dengan metode tanya jawab yang mendorong siswa untuk bisa lebih bebas mengeluarkan pendapat mereka tentang pertanyaan yang diberikan oleh guru, siswa juga dilatih untuk saling menghargai pendapat sesama teman, saling bertoleransi, tidak boleh egois, siswa juga dilatih untuk bisa percaya diri dengan adanya dorongan dan dukungan motivasi dari guru di kelas sehingga proses tanya jawab berjalan dengan baik.

Adapun sikap-sikap demokrasi yang dapat diimplementasikan dalam proses pembelajaran PKn di Sekolah Dasar Negeri 204 Palembang diantaranya (1) Kebebasan berpendapat, yaitu setiap peserta didik memiliki hak untuk berpendapat dan bertanya. (2) Toleransi, setiap peserta didik belajar untuk bertoleransi dengan perbedaan yang ada di antara teman temannya. (3) Kepercayaan diri, sikap percaya diri salah satunya dibentuk melalui metode yang diberikan oleh guru di dalam kelas. (4) Kesadaran akan perbedaan, yaitu kesadaran untuk menerima perbedaan yang ada di dalam kelas sejalan dengan prinsip dan sikap-sikap demokratis. (5) Menghormati orang lain, menghormati orang lain dalam berdemokratis merupakan salah satu nilai yang harus disiapkan sebelum demokrasi dijalankan. 


\section{DAFTAR PUSTAKA}

Amirudin, Abdullah dkk. (2019). Penerapan Metode Project Citizen dan Discovery dalam Pembelajaran Pendidikan Kewarganegaraan untuk Meningkatkan Minat Belajar Siswa. Jurnal.

Hendra, AW. (2008). Faktor-Faktor yang Mempengaruhi Pengetahuan. Jakarta: Pustaka Sinar Harapan.

Hermafitria, dkk. (2015). Implementasi Sikap Demokrasi dalam Proses Pembelajaran Pendidikan Kewarganegaraan Pada Mahasiswa IKIP PGRI Pontianak. Jurnal Sosial Horizon

Narwanti, Sri. (2011). Pendidikan karakter. Yogyakarta: Familia

Novan Ardy, Muhamad, Irham dan Wiyani,. (2013). Psikologi Pendidikan, Teori dan Aplikasi dalam Proses Pembelajaran. Jogjakarta: Ar-Ruzz Media.

Paramita, Tera. (2016). Implementasi Nilai Demokrasi di SD Muhammadiyah. Skripsi Universitas Negeri Yogyakarta.

Rosyada, Dede. (2004). Paradigma Pendidikan Demokratis. Jakarta: Kencana.

Susanto, Ahmad. (2016). Teori Belajar dan Pembelajaran. Jakarta: Penerbit Prenadamedia Grup.

Zamroni. (2013). Pendidikan Demokrasi. Yogyakarta: Ombak. 